\title{
Gender based participatory approach for sustainable small holder farming in developing countries
}

\author{
Sucheta Singh $^{*}$, Sudha Jukaria ${ }^{2}$ and A.K. Sharma ${ }^{3}$ \\ ${ }^{1}$ Farm Science Center, Dhanauri, Haridwar (Uttarakhand), INDIA \\ ${ }^{2}$ Farm Science Center, Jeolikote, Nainital (Uttarakhand), INDIA \\ ${ }^{3}$ Department of Vegetable Science, College of Agriculture, G.B. Pant University of Agriculture \& Technology, \\ Pantnagar (Uttarakhand), INDIA \\ *Corresponding author. E-mail: drsuchetasingh@gmail.com
}

Received: October 21, 2013; Revised received: March 20, 2014; Accepted; March 26, 2014

\begin{abstract}
Dairying at the household level is largely the domain of women. They are contributing for more than $90 \%$ of household activities. In livestock management activities, males are contributing only about $10 \%$ in form of fodder arrangement, livestock management such as, vaccinations, artificial insemination and selling milk. Considering women' participation in dairy production system, their different needs and widening gaps the need was felt to have a study on this aspect. The paper describes rationale and importance of the participatory rural appraisal (PRA) approach. The methodology involves the following sequential components: site selection, site description and categorization, planning for PRA, diffusion of results. In this paper, the planning and implantation of integrated interventions have been made to assess women empowerment in dairy production system and improve dairy productivity. The Neeli ravi breed of buffalo was giving higher yield of milk (average 8 liters per day) over the indigenous breed (average 6-7 liters per day). Among the cow the cross bred was giving an average milk yield of $10 \mathrm{lt} / \mathrm{day}$ which was more than the 5-6 It/day given by the indigenous breed. The occurrence of diseases was mainly June to September and the management practices were carried before their onset in May-June only. But, it should be carried out throughout the year for various diseases. The matrix ranking of technology adoptions for buffalo breeds were found to be 34 points against the 26 points for the indigenous breeds.
\end{abstract}

Keywords: Dairy production system, Gender empowerment, Participatory approach, Sustainable farming

\section{INTRODUCTION}

Agriculture is the backbone of the Indian Economy said Mahatma Gandhi six decades ago. Although agriculture contributes only $17.1 \%$ of India's Gross Domestic Product, its importance in the country's economic, social, and political fabric goes well beyond this indicator. The rural areas are still home to some 72 percent of the India's 1.1 billion people, a large number of whom are poor. Most of the rural poor depend on rain-fed agriculture and fragile forests for their livelihoods (FET, 2010).

The low productivity of small holder farming systems and enterprises is attributed mainly to the limited resources of farming, household and to the application of inappropriate skills and practices that can lead to poor economy (ILRI, 2000; Tulachan et al., 2002). Other subsidiary enterprises to the agriculture contribute to the better economic output.

Dairying is an integral part of Indian agriculture and Indian economy, more so, the rural economy (Zandstra et al., 1981). At the household level, dairying plays an important role in improving the economic condition of farm families. The sector provides insurance against crop failures and helps directly in increasing the crop production by making available the draught power, organic manure and cash income on a regular and day to day basis. In addition, dairying is crucial in providing assured employment to family labour (Sah, 1986; Rajagopalan, 1996; Devendra, 2007). Dairy farming in India continues to be a household enterprise of farm families, where both the genders, i.e. men and women contribute by participating in performing various dairying activities and taking decisions (Bhasin, 1997; Gupta, 1997). Dairying at the household level is largely the domain of women (Manorama Year Book, 1988; Sah et al., 2002). Increasing milk production from cattle and buffaloes is a national priority in most developing countries, because milk is one of the most important foods in human nutrition. Identifying ways to increase milk production is therefore a major challenge. Such approaches include increasing animal numbers and individual production, greater efficiency in natural resource management and better processing and marketing. National perspective plan for women too describes the challenges ahead in following words: "In case of animal husbandry, developmental strategies have provided very little attention to women in comparison to their involvement in both the sectors" (Suresh, 1995).

Feeding and nutrition for example is a key factor that influences low milk production and is influenced by 
itself by such factors as low feed availability, poor feed quality, low feed intake, deficient and imbalanced diets, lack of knowledge of nutritional requirements, periods of feed scarcity and low water supply. Technology empowerment of rural women is identified as a crucial element to ease out their work stress, reduce drudgeries and to improve productivity. Considering women's participation in dairy production system, their different needs and widening gaps the need was felt to have a study on this aspect. The objective of the study was to find out a major subsidiary occupation of small holder farming community. It also elicits the rationale and importance of the Participatory rural appraisal (PRA approach to enable constraint analysis, to understand the complexities of system and to improve integrated dairy productivity. Implicit in this objective is PRA, which focused on the dairy production system with the subsequent addition of cattle animals. The paper not only elicits the information regarding the dairy production system but also provides the insight into the problem identification not only by the policy makers but by the policy users. It helps in defining solutions for the main problem of the lower milk production with a aim to allow planning and implantation of integrated interventions to assess women empowerment in dairy production system and improve dairy productivity.

\section{MATERIALS AND METHODS}

The methodology involves the following sequential components: site selection, site description and categorization, planning for Participatory rural appraisal (PRA). PRA is the development of farming system research, which involves active participation of farm women to identify constraints and plan appropriate solutions.

Site selection: Based on the secondary data of the census in which the dairy was taken up as the main subsidiary occupation by the farmers, the purposive random sampling was used to select the village: Banskhedi, Block: Kashipur in the state: Uttarakhand. In the village, 25 farm households were selected using simple random sampling method among them the key informant was head of the families.

Site description and categorization: Site description provides the details about the site which was selected for the study. The village selected is well described the next heading of results and discussion which was categorized as a village with small and marginal farmers engaged in mainly farming and livestock production.

Planning for PRA: PRA is a research technique developed in early 1980s as an alternative and complement to conventional sample survey. PRA is a way of learning from and with farmers to investigate, analyze and evaluate constraints and opportunities and to formulate research plan to address the problems. The complexities of problem involved in agriculture can be understood through PRA and hence, it is a system approach for systematic and rapid collection of information (Ellman, 1981; Theis and Grady, 1991).

PRA is a systematic, semi structured activity conducted on site, by a multidisciplinary team. It is basically a bottom to top approach of learning rural life forms with and by rural people. Due to active participation of community members as well as scientists, PRA has become a useful method to focus attention on people, their livelihood and relationship with social and economic factors (Cronroy, 2005 and Pezo, 2002). It is a good technique to help the community members make an appraisal of their livelihoods and issues related to it.

Diverse information is collected during PRA using a number of techniques. This information is verified by triangulation among various key informants (KIs) in addition to on-site observation by the team members. The various techniques used by the Focussed Extension Personnel Team (FET) team to collect information are: i) Direct observation, collection and verification of primary data,ii) Collection of secondary data from panchayat members and officials of the State Department of Agriculture, iii) Semi structured interview by raising some general issues to motivate villagers' participation in different aspects of the village, iv) Collection of detailed views by approaching some representative key informants, v) Use of snowball technique to know more about some specific issues, vi) Participatory mapping for rapport building, easy interaction and spontaneous involvement, vii) Seasonal analyses to understand different time bound farm activities, problems and opportunities throughout the year, viii) Problem identification and preference ranking to identify the top most problems and preparing solution plan accordingly.

\section{RESULTS AND DISCUSSION}

Agro-ecological map: Agro-ecological map indicates the macro and micro ecological (subsystem) features in a village. The meteorological parameters like rainfall, temperature, relative humidity, flora and fauna of the village and the basic land use pattern such as agro-forestry, forest cover and wasteland is depicted in the map. The village Banskheri, block: Kashipur, state: Uttarakhand in India was selected with purposive random sampling for the study because it has most of the farmers as small and medium farmers having scope dairy farming as subsidiary occupation. The village Banskheri is located at $7 \mathrm{~km}$ towards east from Kashipur (Fig. 1). It is situated at latitude $29^{\circ} 10^{\prime} \mathrm{N}$ longitude $78^{\circ} 55^{\prime} \mathrm{E}$ and altitude of 209 Meters above sea level. The area is characterized by hot summer and cold winter and medium to high rainfall. Majority of total annual rainfall is recorded in the period of June to September. The soil type is predominantly sandy loam soils in the village.

General transect: The table 1 shows the resources required for the animal husbandry available in the 


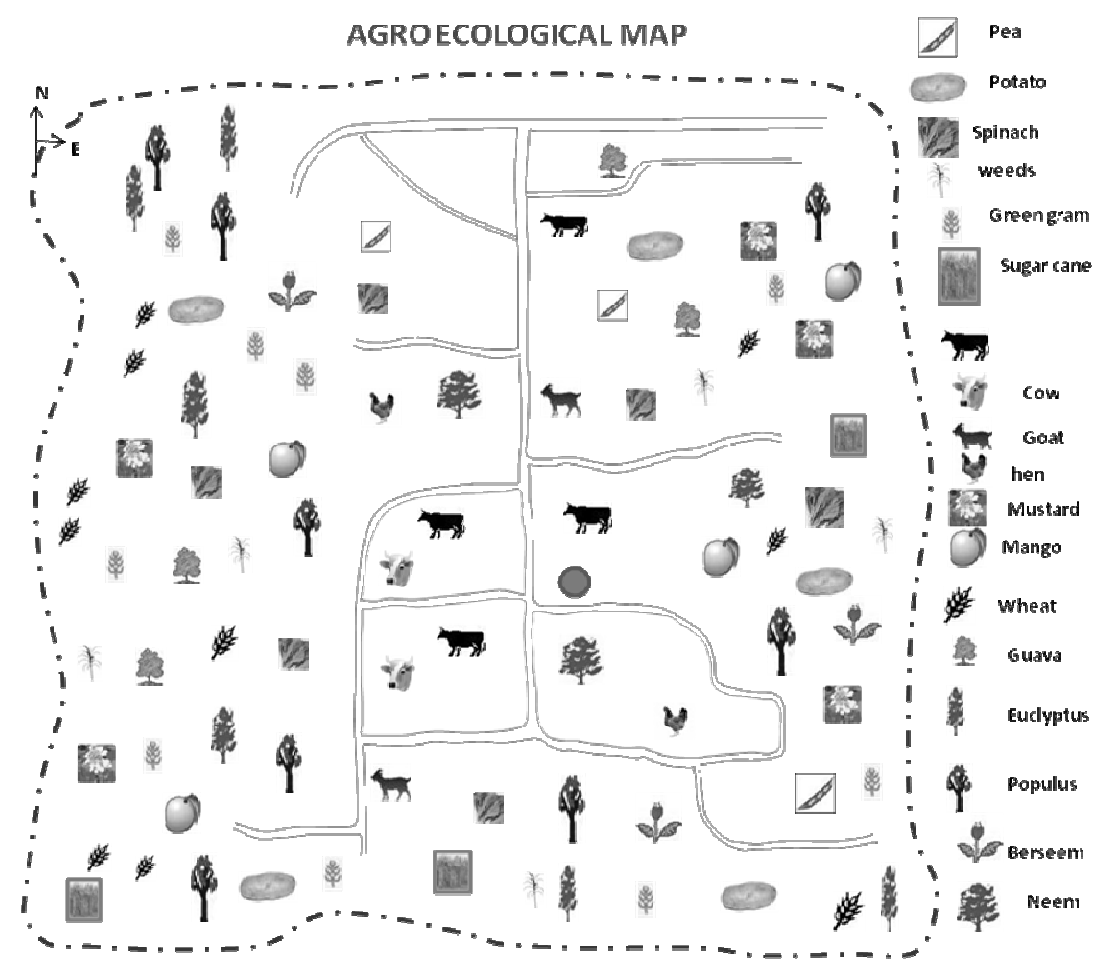

Fig.1. Agro-ecological map of Banskheri village depicting the various agricultural and ecological resources of the village.

vicinity of the village Banskheri. In the south north as well as east west directions of the village there were buffalo, cow, goat and backyard poultry. In trees of the south north direction the poplar, eucalyptus and guava were more whereas, in the east west were neem, poplar, ber, guava and mango. Water resource was bore well in the villages. The problems found were of insect pest diseases, wild animals in the south north and pests and diseases, low milk production of livestock, lack of amenities at market place in the east west. The opportunities made out were adoption of pest management practices and fresh water fish farming in the south north direction whereas, canal construction, regulatory market, IPM for efficient management of pests, bio-gas plant, poultry farm can be introduced in the east west direction of the village.
Animal husbandry: The table 2 depicts the population of various animal and economic yield incurred by the villagers from the products of the village Banskheri. The neeli ravi breed of buffalo was giving higher yield of milk (average 8 liters per day) over the indigenous breed (average 6-7 liters per day). Among the cow the cross bred was giving an average milk yield of $10 \mathrm{lt} /$ day which was more than the 5-6 lt/day given by the indigenous breed. There were 70 buffalo bullocks in the village used for the draught purpose and natural insemination, 50 ox used for draught purpose and 20 backyard poultry units used for chicken and eggs.

Livestock health management practices and problems: Farmers of Banskheri are having mainly local breed of buffaloes, goat and cow. They are giving

Table 1. General transect of Banskheri village.

\begin{tabular}{|c|c|c|c|}
\hline S.N. & Particulars & South North & East West \\
\hline 1 & $\begin{array}{l}\text { Livestock/ Poultry/ } \\
\text { Fish }\end{array}$ & $\begin{array}{l}\text { Buffalo, Cow, Goat, Backyard } \\
\text { Poultry }\end{array}$ & Buffalo, Cow, Goat, Backyard Poultry \\
\hline 2 & Trees & Poplar, Eucalyptus, Guava & Neem, Poplar, Ber, Guava, Mango \\
\hline 3 & Water Sources & Bore Well & Bore Well \\
\hline 4 & Problems & $\begin{array}{l}\text { Insect - Pest and diseases, wild ani- } \\
\text { mals }\end{array}$ & $\begin{array}{l}\text { Pests and diseases, low milk production } \\
\text { livestock problems, lack of good ameni- } \\
\text { ties at market place }\end{array}$ \\
\hline 5 & Opportunities & $\begin{array}{l}\text { Adoption of pest management prac- } \\
\text { tices, fresh water fish farming }\end{array}$ & $\begin{array}{l}\text { Canal construction, regulatory market, } \\
\text { IPM for efficient management of pests, } \\
\text { bio-gas plant, poultry farm can be } \\
\text { introduced. }\end{array}$ \\
\hline
\end{tabular}


Table 2. Type of Animals (Buffalo, Cow, Bullocks, Goat and Poultry) in the Banskheri village.

\begin{tabular}{llll}
\hline \multirow{2}{*}{ Animal } & Population & \multicolumn{2}{c}{ Economic yield } \\
\cline { 3 - 4 } Buffalo & 250(Indigenous) & $6-7$ & Other products (wool and meat) \\
Buffalo & 125 (Neeli Ravi) & 8 & --- \\
Cow & 50 (Indigenous) & $5-6$ & --- \\
Cow & 10 (Cross bred) & 10 & --- \\
Goat & 80 (Indigenous) & --- & --- \\
Buffalo Bullocks & 70 & --- & Meat \\
Ox & 50 & --- & Draught purposes, natural insemina- \\
Backyard Poultry & 20 & --- & tion \\
\hline
\end{tabular}

Table 3. Seasonal calendar of livestock health management practices and problems.

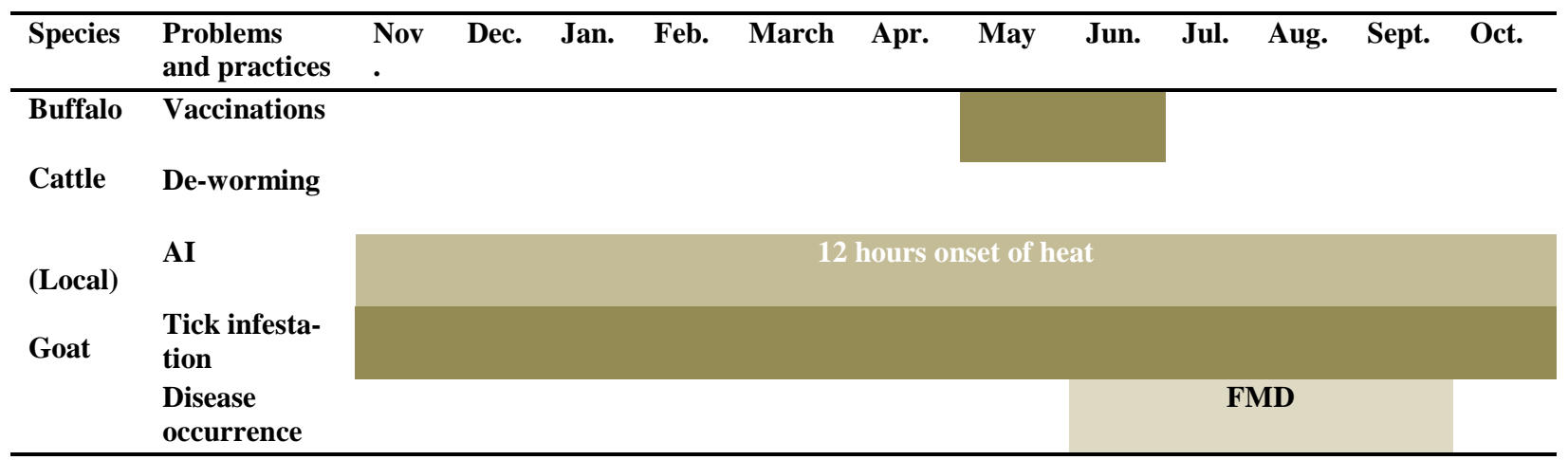

Table 4. Gender disaggregated data for various livestock activities.

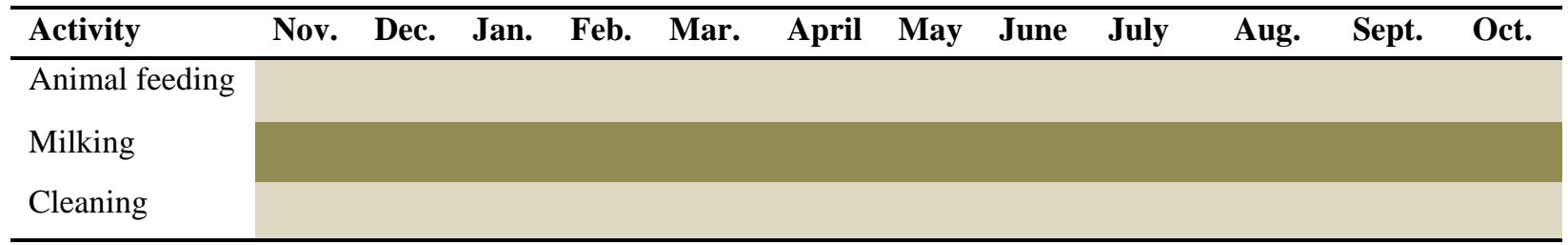

less milk yield. Animals are rare in unhygienic conditions, which is also responsible for low milk yield and results in attack of many diseases and insects' pests attack (Table 3).

The occurrence of diseases was mainly June to September and the management practices were carried before their onset in May-June only. But, it should be carried out throughout the year for various diseases. In recent year, they have started artificial insemination as well as vaccination for various diseases. There is no veterinary hospital in the village, so they arranging veterinary officer from outside through the gram panchayat which has started to do the vaccination and artificial insemination (Francis and Sibanda, 2001). The artificial insemination was used by the villagers throughout the year.

Gender disaggregation: According to information revealed in the table 4 by the key informants, women in Banskheri contributed mainly to livestock management and household activities. Ladies would feed the livestock, milk the animals in the morning, bath them at noon, milk them again in the evening and cut fodder for the animals. They are contributing for more than $90 \%$ of household activities. However male are involving themselves mainly for field activities.

In livestock management activities, male are contributing only about $10 \%$ in form of fodder arrangement livestock management such as, vaccinations, artificial insemination and selling milk. But, generally they do not take part in the activities related to livestock which is carried out throughout the year.

Technologies dissemination in livestock: The details given in the table 5 elucidates the status of various recommended and approved technologies for the animal husbandry of the village Banskheri which in details gives a clear picture of the reasons and efforts behind the technology adoption.

Common animals and breeds reared by the villages in the area are Neeli ravi and indigenous for buffalo, jersey and indigenous for cow in which Neeli ravi buffalo breed and jersey cow breed are recommended 
Table 5. Status of adoption of various technologies for livestock.

\begin{tabular}{|c|c|c|c|}
\hline S. $\mathbf{N}$. & Animal & Status of technology & Stats of technology dissemination \\
\hline 1 & Neeli Ravi Buffalo & Adopted & High milk production, promoted by govt. agencies \\
\hline 2 & Buffalo Indigenous & Over adopted & Well adapted, require less input cost, easy to manage \\
\hline 3 & Jersey cross & $\begin{array}{l}\text { Partially } \\
\text { Adopted }\end{array}$ & $\begin{array}{l}\text { Lack of awareness about breed, Adaptability in local } \\
\text { condition, Artificial Insemination recently adopted }\end{array}$ \\
\hline 4 & Indigenous cow & Over Adoption & $\begin{array}{l}\text { Local adaptability, less management cost, Less milk } \\
\text { yield }\end{array}$ \\
\hline 5 & Buffalo ox & Adopted & $\begin{array}{l}\text { Used in farm operations and bullock cart for draught } \\
\text { purpose }\end{array}$ \\
\hline 6 & Artificial Insemination & Recently Adopted & Non availability of bull, genetic improvement \\
\hline 7 & Silage and hay making & Not adopted & Lack of awareness \\
\hline 8 & Vaccination & Adopted & Promotion by local veterinary doctors \\
\hline 9 & Goat local breed & Adopted & $\begin{array}{l}\text { Alternative source of income, less input requirement, } \\
\text { less fodder requirement. }\end{array}$ \\
\hline
\end{tabular}

Table 6. Matrix ranking of technology adoptions for Buffalo breeds.

\begin{tabular}{|c|c|c|c|c|c|}
\hline \multirow{2}{*}{ Indicators } & \multirow[t]{2}{*}{ KI } & \multicolumn{2}{|c|}{ Indigenous } & \multicolumn{2}{|c|}{ Neeli Ravi } \\
\hline & & Rank & Points & Rank & Points \\
\hline \multirow{4}{*}{ Higher milk yield } & $\mathrm{K} 1$ & $\mathrm{~B}$ & 1 & A & 2 \\
\hline & $\mathrm{K} 2$ & $\mathrm{~B}$ & 1 & A & 2 \\
\hline & $\mathrm{K} 3$ & A & 2 & $\mathrm{~B}$ & 1 \\
\hline & K4 & $\mathrm{B}$ & 1 & A & 2 \\
\hline \multirow[t]{2}{*}{ Score } & & & 5 & & 7 \\
\hline & $\mathrm{K} 1$ & $\mathrm{~B}$ & 1 & A & 2 \\
\hline \multirow{3}{*}{ More lactation period } & $\mathrm{K} 2$ & $\mathrm{~B}$ & 1 & A & 2 \\
\hline & K3 & B & 1 & A & 2 \\
\hline & K4 & $\mathrm{B}$ & 1 & $\mathrm{~A}$ & 2 \\
\hline \multirow[t]{2}{*}{ Score } & & & 4 & & 8 \\
\hline & $\mathrm{K} 1$ & $\mathrm{~B}$ & 1 & A & 2 \\
\hline \multirow{3}{*}{ Fat content } & $\mathrm{K} 2$ & $\mathrm{~B}$ & 1 & A & 2 \\
\hline & K3 & A & 2 & $\mathrm{~B}$ & 1 \\
\hline & K4 & $\mathrm{B}$ & 1 & A & 2 \\
\hline \multirow[t]{2}{*}{ Score } & & & 5 & & 7 \\
\hline & $\mathrm{K} 1$ & $\mathrm{~B}$ & 1 & A & 2 \\
\hline \multirow{3}{*}{ Higher reproductive potential } & $\mathrm{K} 2$ & A & 2 & $\mathrm{~B}$ & 1 \\
\hline & K3 & A & 2 & B & 1 \\
\hline & K4 & $\mathrm{B}$ & 1 & A & 2 \\
\hline \multirow[t]{2}{*}{ Score } & & & 6 & & 6 \\
\hline & $\mathrm{K} 1$ & A & 2 & $\mathrm{~B}$ & 1 \\
\hline \multirow{3}{*}{ More tolerant to diseases } & $\mathrm{K} 2$ & A & 2 & $\mathrm{~B}$ & 1 \\
\hline & $\mathrm{K} 3$ & $\mathrm{~B}$ & 1 & A & 2 \\
\hline & K4 & $\mathrm{B}$ & 1 & A & 2 \\
\hline Score & & & 6 & & 6 \\
\hline Total score & & & 26 & & 34 \\
\hline Rank & & & B & & A \\
\hline
\end{tabular}


improved breeds but indigenous animal breeds are not so good at production. However, a good number of dairy farmers are still continued to rear various indigenous animals due to lack of knowledge, awareness and their poor economic status to purchase improved breeds of animals. In case of buffalo ox and goat they are abide by rearing the local and unidentified breeds.

Artificial insemination, silage and hay making and vaccination of animals are the well proven technologies for enhancement of animal rearing at the best to improve protection and production but their presence in the village is only limited to promotion by local veterinary doctors. Still efforts are needed to improve use of these technologies by the villagers.

Technology adoptions for buffalo breeds (Matrix ranking of buffalo breeds): Table 6 shows the matrix for the animal husbandry towards various breeds in comparison to the local animal breeds preferred by the villagers in the village.

Here, direct matrix ranking was used to list items to be compared along horizontal line and criteria on the vertical line to rank choices for buffalo breeds from most important to least important. In this case frequency of the items valued as the 1 st choice helps to make up a final decision. Direct matrix scoring helps to attach a score to comparable items against each criterion listed before a choice. A comparison could be made out of a score of 10 a comparison could be made between many items against one criteria set, and attach a score out of a maximum of 10 to items to be chosen. The frequencies of the highest scores (closer to 10) attached against many criteria helps to make up a decision for preference. Ranking and scoring was done with villagers as key informants (KI) deliberately selected and with mixed group of men and women. Positive criteria were used for comparison. As a result of matrix ranking method for the adoption of buffalo breeds Neeli Ravi was most preferred over the indigenous breeds by the KIs.

Strategies for increasing milk production: Fig. 2 shows the problems, their causes and the strategies suggested for the problems to increase the milk production which supposed to be the prioritized problem for the village in dairy farming.

Low milk production was the main problem identified responsible for the dairy as non profit venture. The primary causes behind the problems were lack of improved breeds, improper feeding and diseases like foot mouth disease. Unawareness about quality breed, lack of quality feeding material and unhygienic condition in shed were the secondary causes. The teritiary causes identified for the diseases were lack of proper infrastructure and unawareness about needs of animals. The fig. 2 shows that strategies to overcome the aforesaid mentioned causes leading towards low milk production are use of improved breeds, awareness by extension work, proper feeding of animals, use of good feeding material, regular vaccination, proper cleaning of animals and animal shed and proper infrastructure there by increasing the milk production which leads to dairy farming as profitable economic venture.

The study has a further scope as perceived needs of women are related to dairy animal feeding and management while men dairy farmers needs in area of health care and breeding of dairy animals. It is therefore suggested to formulate appropriate strategies to address the needs by means of training, demonstration, campaign etc. As an action approach it can be

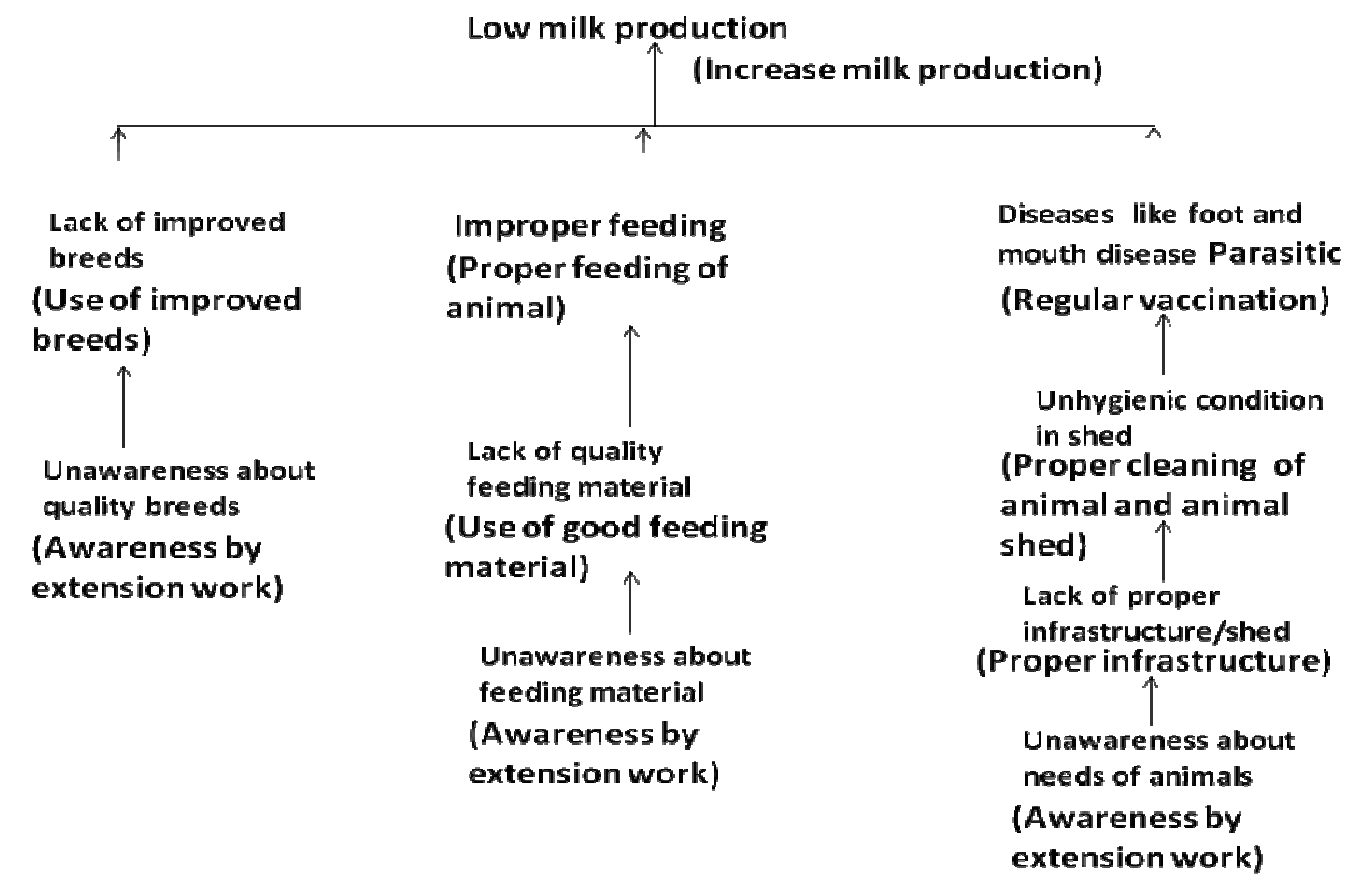

Fig. 2. Problem solution tree for low milk production in village. 
recommended that there is a poor acceptance level of the recommended scientific dairy farming practices.

\section{Conclusion}

It was concluded that the PRA, which focused on the dairy production system with the subsequent addition of cattle animals proved as an important tool in finding women as producers, livestock health workers, collectors, feed sellers, and fodder producers/sellers, their problems and solutions. Women are participating as group leaders, trainers, and motivators. They are improving their own financial and social status, and in some cases have increased decision-making power in their households. In focus-group discussions the number of women reporting that they made decisions on how to spend household income increased by 49 percent. The scenario of dairying in the village calls for intensive efforts directed towards enhancing milk production, productivity and the acceptance of recommended dairy farming practices at household level.

\section{ACKNOWLEDGEMENTS}

The authors wish to acknowledge Indian Council of Agricultural Research, New Delhi, India; FET scientists for their assistance and G.B.P.U.A \&T. Pantnagar, India for providing funds, technology and facilities for this work.

\section{REFERENCES}

Bhasin, N.R. (1997). Dairying and people. Indian Dairyman, 49(2):12-20.

Cronroy, C. (2005). Participatory Livestock Research: A guide. ITDG Publishing Great Britain.

Devendra, C. (2007). Constraints analysis to improve integrated dairy production systems in developing countries: The importance of participatory rural appraisal. Trop. Anim. Health Prod., 39: 549-556.

Ellman, A. (1981). Rapid appraisal for rural project preparation. Agricultural Administration and Extension, 8:463-471.
FET (2010). Training report of FET trainers at KVK Kashipur, Uttarakhand, India. p.45-110.

Francis, J. and Sibanda, S. (2001). Participatory research experiences in small holder farming in Zimbabwe. Livestock Res. Rural Dev., 13:1-15.

Gupta, P.R. (1997). Dairy India, Dairy India Yearbook. Fifth edition, New Delhi, p.10-33.

ILRI (2000). Improving the contribution of livestock in crop animal systems in rain-fed areas in South East Asia. In: Devendra, C. and Frio, A.S. (eds). (2000). Proceedings of second workshop on crop-animal systems research network, Kunming, China.

Manorama Year Book (1988). National perspective plan for women. Manorama Publishing House. Delhi, India, 23:88-90.

Pezo, D. (ed). (2002). Research approaches and methods for improving crop animal systems in rain-fed areas in South East Asia, ILRI Training Manual 5. Nairobi. Kenya.

Rajagopalan, S. (1996). The Hindu Survey of Indian Agriculture Year book, Chennai, p.39-45.

Sah, A.K. (1986). M.Sc. Thesis, NDRI (Deemed University), Karnal, India. In: Sah, U., Kumar, S. and Fulzele, R.M. (2002). An overview of knowledge level of dairy farmers and farm women related to improved dairy farming practices in India. Agric. Rev., 23(2): 140-144.

Sah, U., Kumar, S. and Fulzele, R.M. (2002). Perceived needs of dairy farmers and farm women related to improved dairy farming in India- An overview. Agric. Rev., 23(1):65-70.

Suresh, S.V. J. (1995). Extn. Edn., 6(2):1185-1187, In: Sah, U., Kumar, S. and Fulzele, R.M. (2002). An overview of knowledge level of dairy farmers and farm women related to improved dairy farming practices in India. Agric. Rev., 23(2):140-144.

Theis, J. and Grady, H. (1991). Participatory rapid appraisal for community development. Save the Child Fund. London.

Tulachan, P.M., Jabbar, M. A. and Saleem, M.A.M. (eds). (2002). Small holder dairy in mixed farming systems of the Hindu Kush- Himalayas: issues and prospects for development, ILRI. Nairobi. Kenya.

Zandstra, H.G., Litsinger, E.C. and Morris, R.A. (1981). A methodology for on-farm cropping systems research, IRRI Los Banos, Phillippines. 